\title{
Contemporary and historical influences on the genetic structure of the estuarine-dependent Gulf killifish Fundulus grandis
}

\author{
Dean A. Williams ${ }^{1,2, *}$, Stacy D. Brown ${ }^{1}$, Douglas L. Crawford ${ }^{1}$ \\ ${ }^{1}$ Marine Biology and Fisheries, Rosenstiel School of Marine and Atmospheric Sciences, University of Miami, Miami, \\ Florida 33149, USA
}

${ }^{2}$ Present address: Department of Biology, 2800 S. University Dr., Texas Christian University, Fort Worth, Texas 76129, USA

\begin{abstract}
In comparison to species living in open marine environments, estuarine-dependent species are expected to exhibit stronger genetic population structure due to dispersal limitations. Estuarine habitats are relatively transitory on geological time scales; thus, populations may not be at migration-drift equilibrium, which could confound estimates of current day gene flow or selection. We used 8 nuclear microsatellite loci to investigate the genetic structure of the estuarine Gulf killifish Fundulus grandis across 10 populations along the northwestern and northeastern Gulf of Mexico. Patterns of isolation by distance, spatial autocorrelation, and assignment tests indicate that dispersal is limited and occurs primarily between neighboring sites. Principal component analysis and Bayesian clustering revealed evidence for genetic discontinuities located in Mobile Bay and western Florida which are near hypothesized biogeographical boundaries. There was also a significant negative relationship between genetic diversity and latitude, a pattern consistent with the presence of hypothesized refugia in the southern Gulf regions during the Pleistocene that later recolonized the northern Gulf. Results suggest that populations may be at or near migration-drift equilibrium at a regional scale (e.g the western Gulf), but that dispersal barriers and potential historical signatures on population structure will need to be taken into consideration at larger spatial scales.
\end{abstract}

KEY WORDS: Genetic structure $\cdot$ Isolation by distance $\cdot$ Equilibrium $\cdot$ Estuary $\cdot$ Microsatellites $\cdot$ Gulf of Mexico

\section{INTRODUCTION}

Marine fish inhabiting the open ocean often exhibit low genetic population differentiation due to their large effective population sizes and high dispersal potential (Ward et al. 1994, Waples 1998, Grosberg \& Cunningham 2001). In contrast, species that utilize near-shore habitats such as estuaries and lagoons are expected to exhibit more genetic structure than strictly marine species due to the discontinuous nature of these habitats and their relative isolation from ocean currents (Bilton et al. 2002, Watts \& Johnson 2004). Decreased levels of genetic exchange combined with variable environmental conditions such as salinity and temperature should enhance the genetic divergence and local adaptation of populations in estuarine areas (e.g. Lemaire et al. 2000, Beheregaray \& Sunnucks 2001).

At migration-drift equilibrium, dispersal between these near-shore habitats should approximate a model in which individuals are most likely to disperse to neighboring populations along a single dimension, thereby producing a genetic pattern of isolation by distance (IBD) (Kimura \& Weiss 1964, Crow \& Aoki 1984, Gold \& Turner 2002, Burridge et al. 2004). The transitory distribution of these estuarine habitats on geological time scales, however, may prevent these fish populations from attaining migration-drift equilibrium 
and prevent the formation of IBD genetic structure (Chenoweth \& Hughes 2003, Pampoulie et al. 2004, Durand et al. 2005). Determining the scale over which migration-drift equilibrium may exist in these systems is important since equilibrium is assumed when estimating migration rates using estimators of population subdivision such as Wright's fixation index $\left(F_{\mathrm{ST}}\right)$, or when inferring a signal of natural selection relative to neutral expectations (e.g. Whitehead \& Crawford 2006, Duvernell et al. 2008).

The Gulf of Mexico's coastline and its connections to the Atlantic have undergone many changes. During the Pliocene ( $>1.8$ million years before present [mybp]), sea levels were much higher, much of the Florida landmass was underwater, and the connection between the Atlantic Ocean and Gulf of Mexico was more expansive. During the Pleistocene (1800 000 to 11550 ybp), glaciation captured and stored much water and sea level dropped up to $150 \mathrm{~m}$ (McIntyre et al. 1976, Bloom 1983, Imbrie et al. 1983). With lower sea levels, Florida's shoreline extended 100 miles (ca. $161 \mathrm{~km}$ ) west of its current position, which effectively isolated the Gulf of Mexico's marine populations from Atlantic populations, resulting in a strong genetic discontinuity for many taxa between the Gulf and the Atlantic (Reeb \& Avise 1990, Avise 2000, Soltis et al. 2006). Additionally, Florida's landmass was also much more arid during the glacial maxima ( 18000 ybp), which may have resulted in fewer and more isolated estuarine habitats along the Gulf shore (Avise 1996). During interglacial periods in the Pleistocene, sea levels rose, Florida was a series of islands, and the Gulf and Atlantic Ocean were once again highly connected. Some genetic discontinuities have been described in the northern Gulf (e.g. Felder \& Staton 1994, Gurgel et al. 2004, Bilodeau et al. 2005). During the glacial maxima, temperatures along the northern continental margins of the Gulf coast were 4 to $5^{\circ} \mathrm{C}$ lower than they are today (Brunner 1982). January temperatures were as much as $17^{\circ} \mathrm{C}$ lower than at present in the southeastern United States at this time, suggesting that shallow coastal environments would also have been considerably colder (Stanley 1986). These low temperatures are hypothesized to have forced some near-shore taxa into southern refugia in Mexico and south Florida (Barnwell \& Thurman 1984, Felder \& Staton 1994). With the rise of temperature and sea levels during the interglacial periods, these populations would have expanded back into the northern Gulf. These changes in the Gulf's shoreline, temperature, and connections to the Atlantic should have affected the distribution and population demographics of species inhabiting estuaries.

The Gulf killifish Fundulus grandis is a common inhabitant of salt marshes along the coast from the St.
Johns River in northeastern Florida $\left(30^{\circ} 23^{\prime} 55.93^{\prime} \mathrm{N}\right.$, $\left.81^{\circ} 23^{\prime} 53.47^{\prime} \mathrm{W}\right)$ to Laguna de Tamiahua, Veracruz, Mexico $\left(21^{\circ} 35^{\prime} 36.51^{\prime} \mathrm{N}, 97^{\circ} 33^{\prime} 07.73^{\prime} \mathrm{W}\right.$ ) (Lee et al. 1980). We used nuclear microsatellite loci to investigate the population genetic structure of F. grandis throughout much of its range in the Gulf of Mexico. F. grandis deposits its eggs in dense mats of marsh vegetation that are usually only flooded during biweekly high tides every 2 wk (Greeley \& MacGregor 1983). After an incubation period of about $2 \mathrm{wk}$, the returning tide induces hatching and the larvae then complete their development in the intertidal marsh. This egg stranding reproductive strategy is predicted to promote the retention of offspring in the natal estuary and contribute to significant genetic structure between estuaries. Direct estimates of adult dispersal distance are not known for $F$. grandis. Mark-recapture dispersal estimates for the closely related $F$. heteroclitus, which inhabits salt marshes along the Atlantic coast of North America, ranged from $200 \mathrm{~m}$ to $3.6 \mathrm{~km}$ within a single year (Sweeney et al. 1998, Skinner et al. 2005). If the genetic structure of $F$. grandis is predominantly shaped by current-day dispersal and distributional patterns, we would expect to find a pattern of IBD across the Gulf with significant genetic differentiation among populations due to low levels of dispersal. Alternatively, if past climatic events have had a significant impact on the genetic structure of $F$. grandis in the Gulf, then we might expect to find a lack of IBD across the Gulf, evidence for secondary contact in the northern Gulf between previously separated populations, and evidence of a negative relationship between latitude and genetic diversity.

\section{MATERIALS AND METHODS}

Sampling. Fundulus grandis were collected from 10 locations across the Gulf of Mexico from August 2005 to October 2006 either using baited minnow traps and seine nets, or they were purchased from local bait shops (Fig. 1). We attempted to capture this species at several sites along the southwestern coast of Florida (near Naples) and on the eastern coast near Miami; however, we were not successful in capturing any individuals in these areas. Four samples $(100 \%$ of Kiln County, $100 \%$ of Lake Charles, $30 \%$ of Dauphin Island, and $50 \%$ of Sarasota individuals; see Table 1) were obtained at bait shops. The owners could verify the capture site for all of these populations. A total of 440 individuals were analyzed, with $40 \pm 5.47$ (mean \pm $\mathrm{SE}$ ) individuals collected from each location (see Table 1).

DNA was extracted from dried fin clips. The tissue was placed in $300 \mu \mathrm{l}$ lysis buffer $(75 \mathrm{mM} \mathrm{NaCl}, 25 \mathrm{mM}$ 


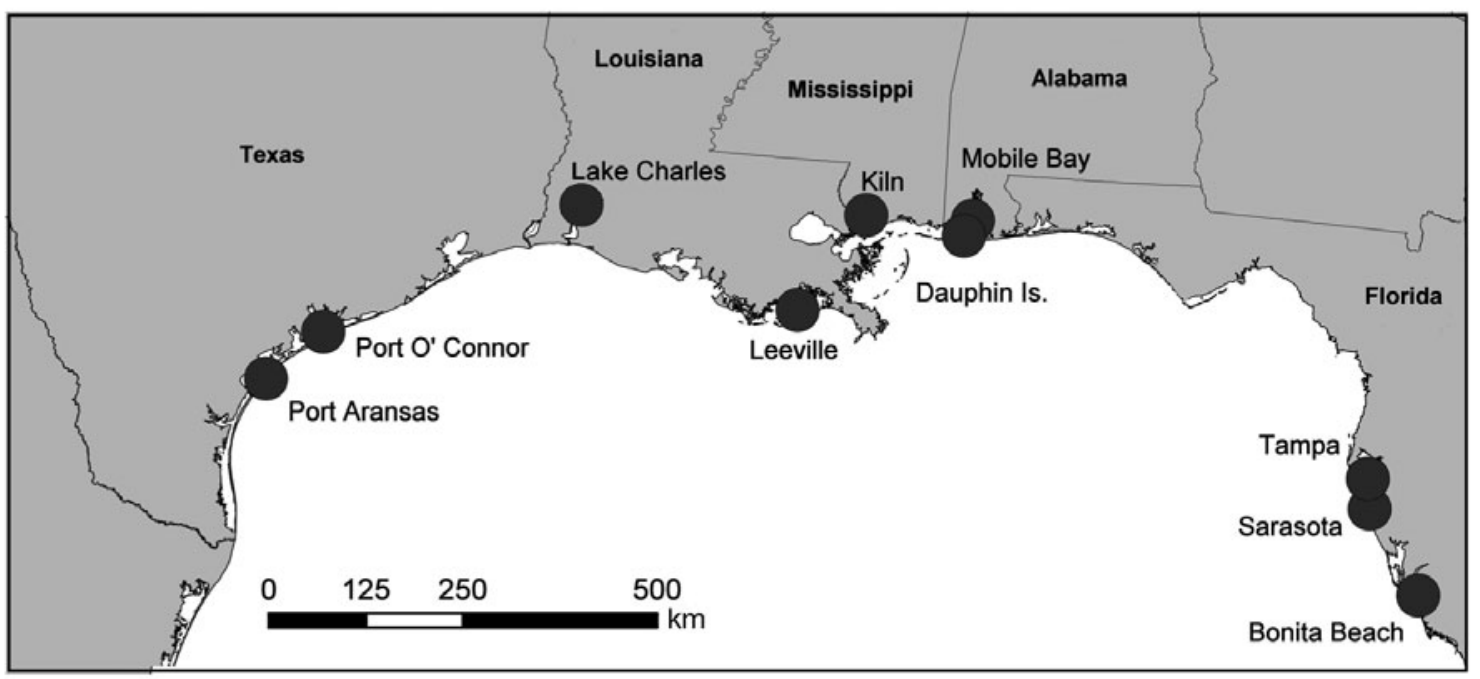

Fig. 1. Sampling localities of Fundulus grandis in the Gulf of Mexico

EDTA, 1\% sodium dodecyl sulphate [SDS]) and incubated with $0.1 \mathrm{mg}$ Proteinase $\mathrm{K}$ at $55^{\circ} \mathrm{C}$ for $2 \mathrm{~h}$. Proteins were precipitated by adding a half volume of $7.5 \mathrm{M}$ ammonium acetate followed by centrifugation for 10 min. DNA was precipitated from the supernatant by adding 0.7 volume of isopropanol followed by centrifugation for $15 \mathrm{~min}$. The DNA pellet was washed with $70 \%$ ethanol, allowed to air dry for $30 \mathrm{~min}$, and then resuspended in $50 \mu \mathrm{l} 10 \mathrm{mM}$ Tris- $\mathrm{HCl} \mathrm{pH}$ 8.5.

DNA amplification and genotyping. We optimized 8 microsatellite loci previously characterized for Fundulus heteroclitus (Adams et al. 2005) for F. grandis in 3 fluorescently labeled multiplex primer groups containing the following final concentrations: A $(0.05 \mu \mathrm{M}$ ATG-B101, $0.05 \mu \mathrm{M}$ ATG-25, $0.075 \mu \mathrm{M}$ ATG-20), B (0.075 $\mu \mathrm{M} C A-1,0.05 \mu \mathrm{M}$ ATG-12), and C (0.06 $\mu \mathrm{M}$ ATG-18, $0.06 \mu \mathrm{M}$ ATG-B4, $0.06 \mu \mathrm{M}$ ATG-B103). Each $10 \mu \mathrm{l}$ reaction contained $2.5 \mathrm{mM} \mathrm{MgCl}, 1 \mathrm{X}$ PCR buffer, $0.2 \mathrm{mM}$ dNTPs, $0.4 \mathrm{U}$ Taq DNA polymerase, $70 \mathrm{ng}$ DNA, and one of 3 primer multiplexes (see above for concentrations). The PCR thermal cycling profile consisted of $94^{\circ} \mathrm{C}$ for $2 \mathrm{~min}$, followed by 31 cycles of $94^{\circ} \mathrm{C}$ for $15 \mathrm{~s}, 55^{\circ} \mathrm{C}$ for $15 \mathrm{~s}$, and $72^{\circ} \mathrm{C}$ for $30 \mathrm{~s}$, ending with a 5 min extension step at $72^{\circ} \mathrm{C}$. Following PCR amplification, the products were electrophoresed on an $\mathrm{ABI}$ 3730XL Genetic Analyzer (Applied Biosystems). All loci that did not amplify were reamplified in single locus reactions at least 2 times. Individuals that did not produce PCR products for more than half of the loci were discarded from the analyses.

We used GENEMAPPER version 4.0 (Applied Biosystems) to score the genotypes. All genotypes were checked by 2 individuals (D. A. Williams and S. D. Brown). To estimate our genotyping error rate, we extracted DNA from a duplicate set of fin tissue taken from a random subset of individuals $(n=53)$ across most populations and genotyped them at all loci. All of the test genotypes were identical to previously determined genotypes, indicating that our error rate was very low $(<2 \%)$.

Statistical analysis. We tested the loci for deviation from Hardy-Weinberg equilibrium and linkage disequilibrium using GENEPOP version 3.3 (Raymond \& Rousset 1995). The number of alleles $\left(N_{\mathrm{A}}\right)$, observed heterozygosity $\left(H_{\mathrm{O}}\right)$, and expected heterozygosity $\left(H_{\mathrm{E}}\right)$ were calculated using GenAlEx6 (Peakall \& Smouse 2006). Allelic richness $\left(A_{R}\right)$ for each locality was calculated using FSTAT version 2.9.3 (Goudet 2001) with a sample size adjustment of $\mathrm{n}=17$ individuals (the smallest sample size).

We used the program MICRO-CHECKER (Van Oosterhout et al. 2004) to infer whether heterozygote deficits within a population may have been due to technical difficulties such as null alleles, scoring difficulties due to stutter, or large allele dropout. Alternatively, biological processes such as population substructuring (i.e. Wahlund effect), inbreeding, and genetic bottlenecks can also cause heterozygote deficits in populations. These processes should generally produce consistent heterozygote deficits across all or most loci, whereas technical difficulties usually only affect one or a few loci. When null alleles were inferred at a locus, we estimated their frequency using Brookfield's equation, which assumes that nonamplifications are a result of null allele homozygotes (Brookfield 1996). We then corrected all allele frequencies for that locus before estimating levels of genetic diversity and calculating levels of differentiation.

The program BOTTLENECK (Cornuet \& Luikart 1996, Piry et al. 1999) tested for the genetic signature of a recent reduction in the effective population size $\left(N_{\mathrm{e}}\right)$ in all samples. Populations that have experienced 
a reduction in $N_{\mathrm{e}}$ are expected to have excess $H_{\mathrm{E}}$ relative to that expected under mutation-drift equilibrium. This occurs because allelic richness is lost at a significantly faster rate than heterozygosity after a population reduction. We evaluated all 3 mutation models (infinite allele model [IAM], 2 phase mutation model [TPM], and stepwise mutation model [SMM]). A Wilcoxon sign-rank test was then used to determine if a significant number of loci exhibited excess heterozygosity (Cornuet \& Luikart 1996). We also used a graphical method to look for evidence of a bottleneck by plotting the number of alleles in 7 allele frequency categories (Luikart et al. 1998). A population that has not experienced a bottleneck is expected to show an Lshaped distribution (many low frequency alleles and few high frequency alleles), whereas bottlenecked populations will exhibit a mode shift.

Differentiation among populations was calculated in FSTAT using the $F_{\mathrm{ST}}$ analog theta (Weir \& Cockerham 1984). We tested for pairwise differences between populations using the log likelihood statistic $G$ (Goudet et al. 1996) (not assuming Hardy-Weinberg equilibrium) in FSTAT. To illustrate the relationships among populations we used principal component analysis (PCA) of allele frequencies using PCAGEN (www2.unil.ch/popgen/softwares/pcagen.htm). The significance of the axes was calculated based on 10000 permutations. We tested for IBD by correlating pairwise $F_{\mathrm{ST}} /\left(1-F_{\mathrm{ST}}\right)$ between populations with geographic distance using 1000 permutations in a Mantel test in GenAlEx6. We also tested for genetic spatial autocorrelation using GenAlEx6 (Peakall \& Smouse 2006). The autocorrelation coefficient, $r$, is a measure of the genetic similarity between populations that fall within a defined distance class. The significance of $\mathrm{r}$ is determined by random permutation of all populations among distance classes and recalculating $\mathrm{r} 1000$ times to set the upper and lower $95 \%$ confidence limits around this value. If the $r$ value fell above or below these limits, then significant spatial structure was inferred. We also calculated 95\% CI around each $\mathrm{r}$ value by bootstrapping $\mathrm{r}$ values within each distance class 1000 times. If these 95\% CI did not include $r=0$, then significant spatial structure was inferred. We also used a simple assignment test to ask whether more individuals would be assigned to their population of capture or to neighboring populations than to populations further away as expected by a stepping stone model of dispersal. Individuals were assigned to populations in which they had the highest log likelihood score using the Bayesian based assignment method of Rannala \& Mountain (1997) in GeneClass2 (Cornuet et al. 1999, Piry et al. 2004).

A Bayesian clustering method implemented in the program STRUCTURE version 2.1 was used to estimate the number of populations $(K)$ in the Gulf of
Mexico and to assign individuals to these populations (Pritchard et al. 2000, Pritchard \& Wen 2003). The membership of each individual in a population was estimated using the ancestry coefficient $q$, which varies on a scale from 0 to 1.0 , with 1.0 indicating full membership. We ran the Monte Carlo Markov Chain (MCMC) for $10^{6}$ iterations following a burn-in period of $10^{5}$ iterations for $\mathrm{K}=1$ to 10 using the correlated allele frequencies model and assuming admixture (the default values) 10 times. The most likely $\mathrm{K}$ was then estimated using the method of Evanno et al. (2005).

\section{RESULTS}

All loci were highly polymorphic, with an average of $22.1 \pm 3.4$ alleles per locus (range $=13$ to 35 alleles) for all populations combined (Table 1). None of the pairwise comparisons between loci within populations exhibited significant genotypic linkage disequilibrium after Bonferroni correction $(p<0.0001)$. This suggests that the loci we used provide independent measures of genetic diversity and genetic structure. We found no significant heterozygote excess in any sample. However, there was a significant heterozygote deficit at locus ATG-25 in 2 populations and at loci ATG-B101, ATG-B4, and CA-1 in the Bonita Beach population (Table 1). The lack of a clear pattern across loci or populations suggests that genetic bottlenecks or population admixture were unlikely explanations for the observed heterozygote deficits. The MICROCHEKER analysis indicated taht the most likely technical cause of these deficits was null alleles rather than problems associated with scoring stutter peaks or large allele drop out.

None of the tests for a genetic bottleneck was significant. There was not a significant excess of heterozygosity relative to equilibrium expectations under any mutation model nor was there evidence of a mode shift in the frequency distribution of alleles (data not presented).

Average allelic richness across the 8 loci decreased with increasing latitude $\left(y=-0.36 x+20.5, r^{2}=0.54, p=\right.$ 0.01) (Fig. 2a). The pattern of allelic richness with longitude revealed that the samples from southern Texas and Florida have the highest allelic richness and that allelic richness decreases in populations further north (Fig. 2b). This resulted in a U-shaped distribution of allelic richness with longitude in the Gulf and is best explained with a second order polynomial relationship $\left(y=0.03 x^{2}-4.5 x+207.4, r^{2}=0.87, p=0.001\right)$ (Fig. 2b)

There was significant genetic structure across all 10 populations $\left(F_{\mathrm{ST}}=0.041 \pm 0.02 \mathrm{SE} ; 95 \% \mathrm{CI}=\right.$ $0.02-0.08)$. The average pairwise $F_{\mathrm{ST}}$ between populations was $0.05 \pm 0.004(\mathrm{n}=45$, range $=0.003$ to 0.11$)$ 
Table 1. Fundulus grandis. Genetic diversity measures at microsatellite loci within 10 populations of $F$. grandis. $N=$ number of individuals genotyped, $N_{\mathrm{A}}=$ number of alleles at a locus, $H_{\mathrm{O}}=$ observed heterozygosity (values in bold represent significant heterozygote deficits), $H_{\mathrm{E}}=$ expected heterozygosity, $F_{\mathrm{IS}}=$ inbreeding coefficient (calculated after correction for possible null alleles, see 'Materials and methods'), $A_{\mathrm{R}}=$ allelic richness corrected for sample size using 17 individuals

\begin{tabular}{|c|c|c|c|c|c|c|c|c|c|c|}
\hline Sample (abbreviation) & Statistic & ATG-12 & ATG-18 & ATG-20 & ATG-25 & ATG-B101 & ATG-B103 & ATG-B4 & $C A-1$ & Mean \\
\hline \multirow[t]{6}{*}{ Pt. Aransas (AR) } & $N$ & 34 & 34 & 34 & 34 & 34 & 34 & 34 & 34 & 34.0 \\
\hline & $N_{\mathrm{A}}$ & 12 & 8 & 10 & 13 & 9 & 20 & 20 & 22 & 14.3 \\
\hline & $H_{\mathrm{O}}$ & 1.00 & 0.79 & 0.68 & 0.82 & 0.88 & 0.91 & 0.91 & 0.91 & 0.86 \\
\hline & $H_{\mathrm{E}}$ & 0.89 & 0.82 & 0.65 & 0.86 & 0.80 & 0.92 & 0.92 & 0.94 & 0.85 \\
\hline & $F_{\mathrm{IS}}$ & -0.104 & 0.074 & -0.030 & 0.060 & -0.036 & 0.027 & 0.018 & 0.045 & 0.007 \\
\hline & $A_{\mathrm{R}}$ & 11.0 & 7.1 & 7.6 & 10.6 & 7.0 & 15.3 & 15.6 & 17.7 & 11.5 \\
\hline \multirow[t]{6}{*}{ Pt. O'Connor (OC) } & $N$ & 43 & 43 & 43 & 43 & 43 & 43 & 43 & 43 & 43.0 \\
\hline & $N_{\mathrm{A}}$ & 14 & 7 & 9 & 11 & 10 & 20 & 18 & 19 & 13.5 \\
\hline & $H_{\mathrm{O}}$ & 0.86 & 0.77 & 0.67 & 0.91 & 0.81 & 0.88 & 0.95 & 0.91 & 0.85 \\
\hline & $H_{\mathrm{E}}$ & 0.87 & 0.81 & 0.62 & 0.87 & 0.78 & 0.93 & 0.92 & 0.91 & 0.84 \\
\hline & $F_{\mathrm{IS}}$ & 0.013 & 0.035 & -0.076 & -0.036 & -0.080 & 0.063 & -0.020 & 0.015 & -0.011 \\
\hline & $A_{\mathrm{R}}$ & 11.1 & 6.3 & 7.3 & 9.0 & 7.6 & 15.5 & 14.4 & 14.5 & 10.7 \\
\hline \multirow[t]{6}{*}{ Lake Charles (LC) } & $N$ & 36 & 36 & 36 & 36 & 36 & 36 & 36 & 36 & 36.0 \\
\hline & $N_{\mathrm{A}}$ & 10 & 9 & 9 & 10 & 8 & 17 & 18 & 16 & 12.1 \\
\hline & $H_{\mathrm{O}}$ & 0.81 & 0.72 & 0.44 & 0.92 & 0.75 & 0.92 & 0.94 & 0.86 & 0.80 \\
\hline & $H_{\mathrm{E}}$ & 0.79 & 0.80 & 0.49 & 0.84 & 0.80 & 0.93 & 0.90 & 0.88 & 0.80 \\
\hline & $F_{\mathrm{IS}}$ & -0.002 & 0.109 & 0.121 & -0.073 & 0.037 & 0.027 & -0.036 & 0.003 & 0.023 \\
\hline & $A_{\mathrm{R}}$ & 8.5 & 7.1 & 7.0 & 8.8 & 6.8 & 14.8 & 13.4 & 12.8 & 9.9 \\
\hline \multirow[t]{6}{*}{ Leeville (LV) } & $N$ & 59 & 59 & 59 & 59 & 59 & 59 & 59 & 59 & 59.0 \\
\hline & $N_{\mathrm{A}}$ & 10 & 7 & 8 & 10 & 8 & 21 & 19 & 18 & 12.6 \\
\hline & $H_{\mathrm{O}}$ & 0.81 & 0.83 & 0.46 & 0.75 & 0.73 & 0.97 & 0.88 & 0.83 & 0.78 \\
\hline & $H_{\mathrm{E}}$ & 0.81 & 0.77 & 0.49 & 0.85 & 0.79 & 0.94 & 0.93 & 0.84 & 0.80 \\
\hline & $F_{\mathrm{IS}}$ & 0.033 & -0.080 & 0.072 & 0.076 & 0.088 & -0.026 & 0.066 & 0.035 & 0.033 \\
\hline & $A_{\mathrm{R}}$ & 8.2 & 6.1 & 5.8 & 8.2 & 6.7 & 15.8 & 15.0 & 11.3 & 9.6 \\
\hline \multirow[t]{6}{*}{ Kiln County (KC) } & $N$ & 124 & 123 & 124 & 124 & 124 & 124 & 124 & 123 & 123.8 \\
\hline & $N_{\mathrm{A}}$ & 11 & 13 & 9 & 9 & 9 & 27 & 28 & 20 & 15.8 \\
\hline & $H_{\mathrm{O}}$ & 0.85 & 0.77 & 0.59 & 0.87 & 0.81 & 0.93 & 0.94 & 0.85 & 0.83 \\
\hline & $H_{\mathrm{E}}$ & 0.81 & 0.80 & 0.59 & 0.83 & 0.81 & 0.94 & 0.92 & 0.83 & 0.82 \\
\hline & $F_{\mathrm{IS}}$ & -0.038 & 0.044 & 0.008 & -0.046 & -0.001 & 0.015 & -0.02 & -0.027 & -0.01 \\
\hline & $A_{\mathrm{R}}$ & 8.29 & 7.26 & 5.43 & 7.74 & 6.64 & 16.00 & 14.73 & 10.22 & 9.54 \\
\hline \multirow[t]{6}{*}{ Dauphin Island (DI) } & $N$ & 23 & 23 & 23 & 22 & 22 & 23 & 23 & 23 & 22.8 \\
\hline & $N_{\mathrm{A}}$ & 6 & 8 & 7 & 8 & 8 & 17 & 16 & 11 & 10.1 \\
\hline & $H_{\mathrm{O}}$ & 0.87 & 0.83 & 0.78 & 0.86 & 0.64 & 1.00 & 1.00 & 0.65 & 0.83 \\
\hline & $H_{\mathrm{E}}$ & 0.69 & 0.80 & 0.76 & 0.81 & 0.62 & 0.92 & 0.91 & 0.68 & 0.77 \\
\hline & $F_{\mathrm{IS}}$ & -0.243 & -0.006 & -0.008 & -0.030 & -0.038 & -0.065 & -0.078 & 0.017 & -0.056 \\
\hline & $A_{\mathrm{R}}$ & 5.5 & 7.6 & 6.2 & 7.7 & 7.4 & 15.0 & 14.7 & 9.0 & 9.1 \\
\hline \multirow[t]{6}{*}{ Mobile Bay (MB) } & $N$ & 55 & 55 & 55 & 55 & 55 & 55 & 55 & 55 & 55.0 \\
\hline & $N_{\mathrm{A}}$ & 10 & 8 & 8 & 9 & 8 & 20 & 17 & 19 & 12.4 \\
\hline & $H_{\mathrm{O}}$ & 0.82 & 0.69 & 0.86 & 0.78 & 0.73 & 0.93 & 0.95 & 0.84 & 0.82 \\
\hline & $H_{\mathrm{E}}$ & 0.77 & 0.75 & 0.81 & 0.81 & 0.74 & 0.93 & 0.91 & 0.83 & 0.82 \\
\hline & $F_{\mathrm{IS}}$ & -0.056 & 0.073 & -0.051 & 0.038 & 0.053 & 0.017 & -0.027 & -0.018 & 0.004 \\
\hline & $A_{\mathrm{R}}$ & 7.2 & 7.2 & 6.7 & 7.5 & 6.4 & 15.3 & 13.1 & 11.5 & 9.4 \\
\hline \multirow[t]{6}{*}{ Tampa Bay (TB) } & $N$ & 17 & 17 & 17 & 17 & 17 & 17 & 17 & 17 & 17.0 \\
\hline & $N_{\mathrm{A}}$ & 12 & 6 & 4 & 8 & 11 & 12 & 15 & 18 & 10.8 \\
\hline & $H_{\mathrm{O}}$ & 0.94 & 0.88 & 0.29 & 0.94 & 0.88 & 0.77 & 0.94 & 0.94 & 0.82 \\
\hline & $H_{\mathrm{E}}$ & 0.89 & 0.78 & 0.27 & 0.78 & 0.84 & 0.87 & 0.88 & 0.93 & 0.78 \\
\hline & $F_{\mathrm{IS}}$ & -0.034 & -0.093 & -0.110 & -0.106 & -0.028 & 0.135 & -0.056 & 0.077 & -0.027 \\
\hline & $A_{\mathrm{R}}$ & 12 & 6 & 4 & 8 & 11 & 12 & 15 & 18 & 10.8 \\
\hline \multirow[t]{6}{*}{ Sarasota (SS) } & $N$ & 31 & 31 & 31 & 31 & 31 & 31 & 31 & 31 & 31.0 \\
\hline & $N_{\mathrm{A}}$ & 15 & 7 & 4 & 8 & 13 & 14 & 12 & 17 & 11.3 \\
\hline & $H_{\mathrm{O}}$ & 0.94 & 0.81 & 0.68 & 0.61 & 0.97 & 0.77 & 0.71 & 0.94 & 0.80 \\
\hline & $H_{\mathrm{E}}$ & 0.89 & 0.75 & 0.61 & 0.84 & 0.89 & 0.87 & 0.77 & 0.92 & 0.82 \\
\hline & $F_{\mathrm{IS}}$ & -0.039 & -0.061 & -0.081 & 0.117 & -0.073 & 0.141 & 0.113 & -0.032 & 0.011 \\
\hline & $A_{\mathrm{R}}$ & 12.4 & 6.2 & 4.0 & 8.5 & 11.2 & 12.2 & 10.1 & 14.3 & 9.9 \\
\hline \multirow[t]{6}{*}{ Bonita Beach (BB) } & $N$ & 17 & 18 & 18 & 18 & 18 & 18 & 18 & 18 & 17.9 \\
\hline & $N_{\mathrm{A}}$ & 12 & 6 & 5 & 10 & 8 & 15 & 12 & 18 & 10.8 \\
\hline & $H_{\mathrm{O}}$ & 0.78 & 0.79 & 0.79 & 0.94 & 0.94 & 0.67 & 0.68 & 0.79 & 0.80 \\
\hline & $H_{\mathrm{E}}$ & 0.90 & 0.69 & 0.67 & 0.86 & 0.84 & 0.90 & 0.86 & 0.94 & 0.83 \\
\hline & $F_{\mathrm{IS}}$ & 0.168 & -0.107 & -0.144 & -0.074 & -0.101 & 0.174 & 0.246 & 0.192 & 0.044 \\
\hline & $A_{\mathrm{R}}$ & 12.0 & 5.9 & 4.9 & 9.9 & 7.9 & 14.0 & 11.6 & 17.6 & 10.5 \\
\hline
\end{tabular}




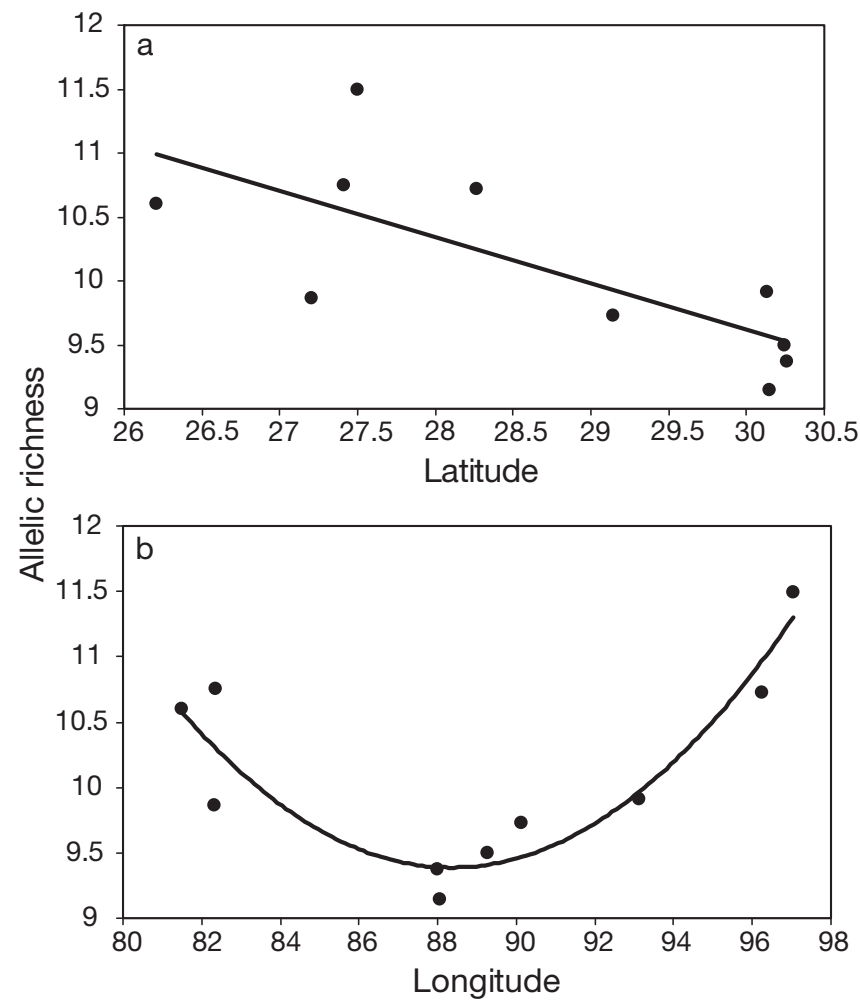

Fig. 2. Fundulus grandis. Relationship of average allelic richness within a population ( $\mathrm{n}=8$ microsatellite loci) and (a) latitude, (b) longitude

(Table 2). Virtually all pairwise comparisons between populations exhibited significant genotypic frequency differences after a Bonferroni correction for multiple tests $(\mathrm{p}<0.001)$ (Table 2). The PCA, which is based on the correlation matrix of allele frequencies between populations, indicated some clear subdivisions among the populations (Fig. 3). The first axis of the PCA (Fig. 3) accounted for $42 \%$ of the variation and clearly discriminated between the Florida populations (Bonita Beach, Sarasota, Tampa Bay) and the rest of the Gulf

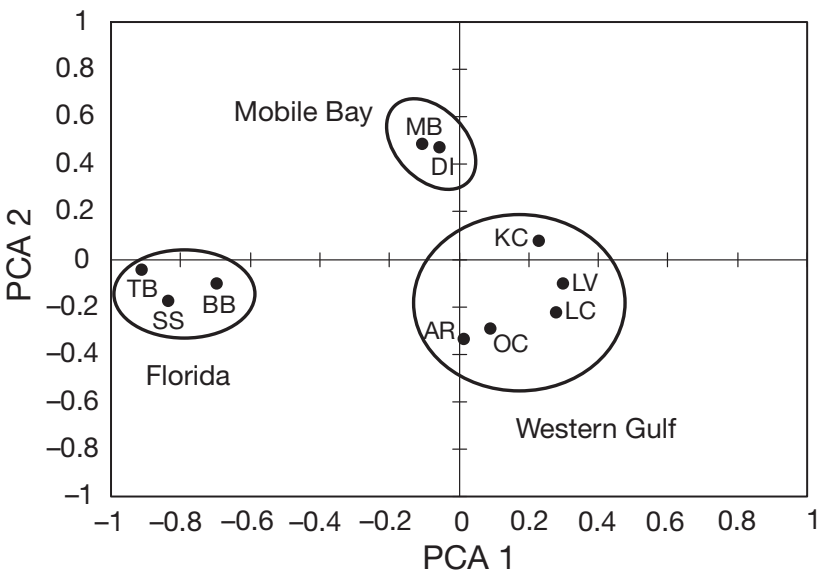

Fig. 3. Fundulus grandis. Principal component analysis (PCA) of allele frequencies in populations of F. grandis. Circles encompass clusters of genetically similar populations. The first axis explains $42 \%$ of the variation ( $p=0.0001)$ and the second axis explains $20 \%$ of the variation $(p=0.0001)$ in allele frequency differences between populations. Abbreviations as in Table 1

populations $(\mathrm{p}=0.0001)$. This can also be seen in the pairwise $F_{\mathrm{ST}}$ values (Table 2), where the average $F_{\mathrm{ST}}$ among Florida populations is 0.027 , yet the mean $F_{\mathrm{ST}}$ between the next geographically close populations in the Mobile Bay area (Mobile Bay and Dauphin Island) and the Florida populations is 0.075, similar to the mean $F_{\mathrm{ST}}$ of 0.080 between Florida populations and all other populations. The second axis accounted for $20 \%$ of the variation and separates the Mobile Bay and Dauphin Island populations from the other Gulf populations and also reveals a pattern of IBD across the western Gulf ( $p=0.0001)$. This separation can also be seen in the pairwise $F_{\mathrm{ST}}$ values (Table 2 ), where among the populations west of the Mobile Bay area the average $F_{\mathrm{ST}}$ is 0.014 , while between Mobile Bay populations and the populations west of them the average $F_{\mathrm{ST}}$ is 0.042 .

Table 2. Fundulus grandis. Pairwise estimates of $F_{\mathrm{ST}}$ between populations of $F$. grandis. Values in bold indicate pairwise comparisons that do not exhibit significant differentiation in genotype frequencies using the log likelihood statistic $G$ after Bonferroni correction. Samples are ordered west to east. Abbreviations as in Table 1

\begin{tabular}{|c|c|c|c|c|c|c|c|c|c|c|}
\hline & AR & $\mathrm{OC}$ & $\mathrm{LC}$ & LV & $\mathrm{KC}$ & DI & $\mathrm{MB}$ & TB & SS & BB \\
\hline $\mathrm{AR}$ & - & 0.003 & 0.014 & 0.022 & 0.025 & 0.055 & 0.044 & 0.075 & 0.061 & 0.049 \\
\hline OC & & - & 0.013 & 0.014 & 0.019 & 0.046 & 0.042 & 0.079 & 0.065 & 0.062 \\
\hline $\mathrm{LC}$ & & & - & 0.004 & 0.014 & 0.051 & 0.045 & 0.106 & 0.087 & 0.078 \\
\hline $\mathrm{LV}$ & & & & - & 0.010 & 0.036 & 0.039 & 0.103 & 0.086 & 0.078 \\
\hline $\mathrm{KC}$ & & & & & - & 0.035 & 0.025 & 0.092 & 0.084 & 0.077 \\
\hline DI & & & & & & - & 0.013 & 0.086 & 0.075 & 0.073 \\
\hline MB & & & & & & & - & 0.069 & 0.072 & 0.054 \\
\hline TB & & & & & & & & - & 0.012 & 0.035 \\
\hline SS & & & & & & & & & - & 0.028 \\
\hline BB & & & & & & & & & & - \\
\hline
\end{tabular}




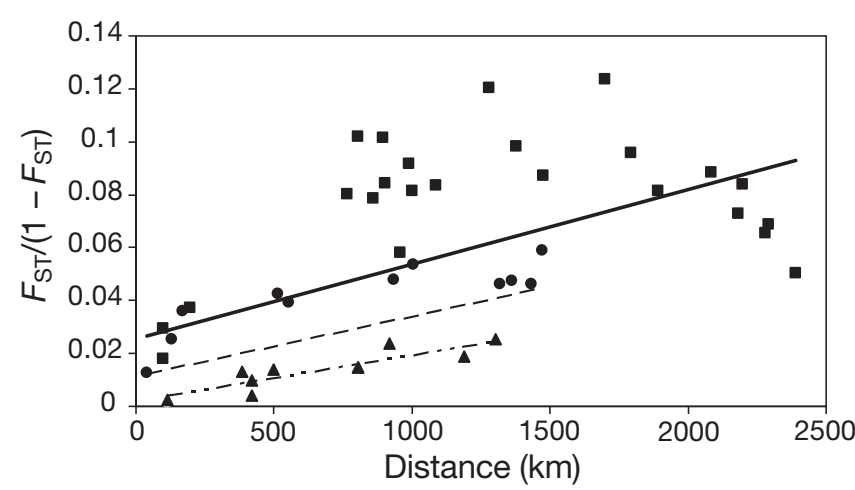

Fig. 4. Fundulus grandis. Relationship between pairwise genetic and geographic distance for 10 populations of F. grandis. Solid line is regression line for all 10 populations $(\boldsymbol{\square}, \boldsymbol{\bullet}, \mathbf{\Lambda}$, $\left.y=3 \times 10^{-5} x+0.025\right)$; dashed line is 7 populations excluding the Florida populations $\left(\bullet, \boldsymbol{\Lambda}, y=2 \times 10^{-5} x+0.011\right)$; dotdashed line is 5 populations west of Mobile Bay $(\boldsymbol{\Lambda}, y=2 \times$ $\left.10^{-5} x+0.002\right)$. $\mathbf{~ : ~ p a i r w i s e ~ c o m p a r i s o n s ~ b e t w e e n ~ F l o r i d a ~ a n d ~}$ all other populations; $\bullet$ : comparisons excluding the Florida populations; $\mathbf{\Delta}$ : comparisons excluding Mobile Bay and Florida populations. $F_{\mathrm{ST}}$ : Wright's fixation index

There was a significant positive relationship between genetic and geographic distance $(\mathrm{r}=0.57, \mathrm{p}=$ 0.01) (Fig. 4). Most of the Florida comparisons with the western Gulf, however, form a cluster of points above the regression line, suggesting that these populations are more differentiated from the rest of the Gulf than predicted by distance alone. At the furthest distances, $F_{\mathrm{ST}}$ drops below the predicted relationship which may indicate the presence of homoplasy. There was still a significant relationship between genetic and geographic distance after removing the Florida samples $(\mathrm{r}=0.61, \mathrm{p}=0.02)$, although these comparisons revealed that the Mobile Bay samples cluster above the predicted relationship (Fig. 4). Comparing only the populations west of Mobile Bay resulted in a strong relationship between genetic and geographic distance $(\mathrm{r}=0.89, \mathrm{p}=0.02)$ with an origin very close to zero as expected when populations with a stepping stone population structure are at migration-drift equilibrium (Fig. 4). The effect of genetic differentiation between the Mobile Bay and Florida populations with the western Gulf populations can be seen in Fig. 4 by an increase in the $y$-intercept of the regression line for genetic versus geographic distance and is consistent with the groupings revealed by the PCA.

There was significant positive genetic spatial autocorrelation for pairwise $F_{\mathrm{ST}}$ values across the entire Gulf only in the $160 \mathrm{~km}(\mathrm{p}=0.001)$ and $480 \mathrm{~km}(\mathrm{p}=$ 0.003) distance classes (Fig. 5), which generally encompasses 2 to 3 of our sampling sites. There was a steep decline in autocorrelation values for populations separated by distance classes of $726 \mathrm{~km}$ or more, with the correlogram crossing the $y$-axis at $\sim 977 \mathrm{~km}$ and

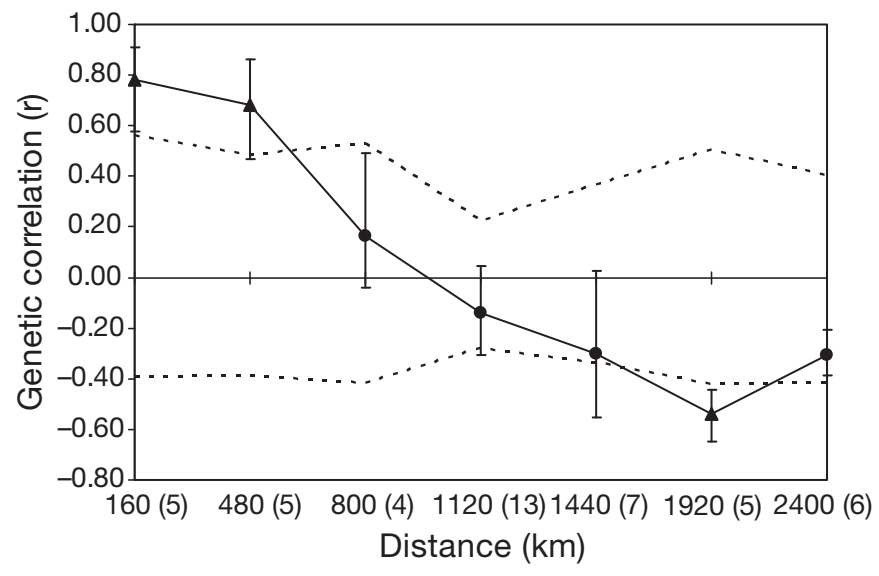

Fig. 5. Fundulus grandis. Genetic spatial autocorrelation of pairwise genetic $\left(F_{\mathrm{ST}}\right)$ and geographic distance for 10 populations of $F$. grandis. Dashed lines are $95 \%$ CI around $r=0$; vertical lines are $95 \%$ bootstrapped CI around each calculated $r$ value. $\mathbf{\Delta}$ : significantly different from $r=0$ ( $p \leq 0.005)$. Numbers in parentheses next to the distance classes are the number of pairwise comparisons in that class

becoming significantly negative at the $1920 \mathrm{~km}$ distance category, reflecting the distinct population clusters of Florida versus the western Gulf revealed by the PCA analysis and STRUCTURE (see below). Restricting the spatial autocorrelation only to the populations west of the Mobile Bay area revealed significant positive spatial autocorrelation in the first of 4 distance classes (160 km, r =0.68, p = 0.02, data not presented).

One assumption of the individual-based assignment tests, such as the assignment method of Rannala \& Mountain (1997) and the algorithm in STRUCTURE, is that the populations are in Hardy-Weinberg equilibrium. We therefore performed the analyses with and without locus ATG-25, which exhibited putative null alleles, since it is not possible to correct allele frequencies for null alleles and retain the correct individual genotypes. We also performed the analyses with and without the Bonita Beach population because it had heterozygote deficits at 3 loci. Excluding locus ATG-25 or the Bonita Beach population had virtually no effect on the final results. The assignment test of Rannala \& Mountain (1997) supported an IBD relationship. Most individuals were assigned to their population of capture $(55.4 \%)$ or to an adjacent population $(29.5 \%)$. STRUCTURE estimated 3 population clusters in the Gulf (Fig. 6). The Florida samples formed the strongest cluster, with an average proportion of ancestry $(q)$ of 89.8\% for Cluster A (Fig. 6). Although the other populations were a mix of the 3 clusters, the proportions of each cluster were strongly related to geography and exhibited a pattern consistent with IBD. Excluding the Florida populations (which were predominantly Cluster A), there was a strong positive relationship be- 


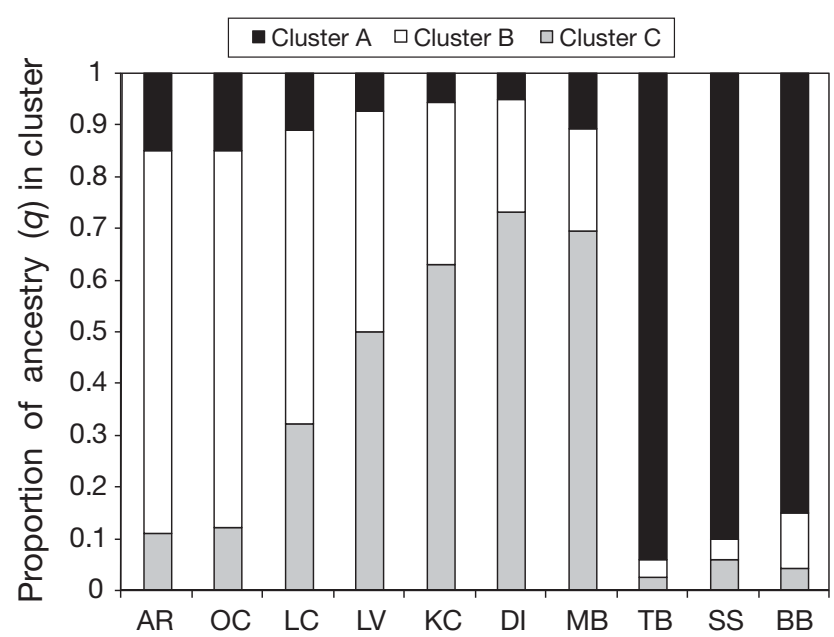

Fig. 6. Fundulus grandis. Proportion of ancestory $(q)$ in each of the 3 clusters determined with STRUCTURE (see 'Material and methods') for each sampling locality of $F$. grandis. Abbreviations as in Table 1

tween longitude and the $q$ that populations contained of Clusters A and B ( $r=0.87,0.99, \mathrm{p}<0.01$, respectively) and a negative relationship between longitude and $q$ that populations contained of Cluster $\mathrm{C}$ ( $\mathrm{r}=$ $-0.99, \mathrm{p}<0.01)$.

\section{DISCUSSION}

Fundulus grandis exhibits significant population genetic structure throughout the Gulf of Mexico. Our data suggest that most dispersal occurs between adjacent estuaries and that several genetic discontinuities exist along the Gulf coast. The Florida populations in particular are significantly differentiated from the more western and northern Gulf populations. Comparisons between the most geographically distant populations (Florida and the western Gulf) revealed a higher similarity in allele frequencies than predicted by distance, which may indicate the occurrence of homoplasy. When effective population sizes are very large, which may be the case for this species, homoplasy is predicted to occur in highly polymorphic markers such as microsatellites (Estoup et al. 2002). Populations at varying scales exhibited a pattern of IBD, and spatial autocorrelation revealed that populations located within $160 \mathrm{~km}$ of each other were more similar than expected at random. Similarly, assignment tests placed most individuals at either their place of capture or in adjacent populations. The clusters determined by the STRUCTURE analysis were also consistent with IBD in the western Gulf.

Estuarine-dependent species, like the Gulf killifish, are expected to exhibit stronger genetic population structure due to dispersal limitations than species living in more open marine environments. Although limited in number, studies of estuarine fish in the Gulf of Mexico have found the expected IBD relationship (Gold \& Richardson 1998, Blandon et al. 2001, Gold \& Turner 2002, present study), whereas studies of reef or pelagic organisms in the Gulf have found broad-scale genetic homogeneity (Herke \& Foltz 2002, Ball \& Chapman 2003, Purcell et al. 2006).

Fundulus grandis shows very similar levels of population subdivision when compared to its closely related congener $F$. heteroclitus which inhabits salt marshes along the Atlantic coast of North America (mean pairwise $F_{\mathrm{ST}}=0.05 \pm 0.004$ for $F$. grandis vs. $0.042 \pm 0.005$ for southern populations of $F$. heteroclitus) (Adams et al. 2006, present study). F. heteroclitus exhibits concordant clines in allele frequencies at allozyme, mitochondrial, and nuclear microsatellite loci, with a strong transition zone occurring at $\sim 41^{\circ} \mathrm{N}$ latitude (reviewed in Adams et al. 2006, Duvernell et al. 2008). Strong patterns of IBD across the entire range of $F$. heteroclitus $(\mathrm{r}=0.85)$ as well as within northern $(\mathrm{r}=0.70)$ and southern populations $(r=0.79)$ suggests that this species was distributed along the entire east coast of North America during the Pleistocene glacial maxima and that subsequent rising sea levels brought previously separated populations into contact and produced the observed transition zone (Adams et al. 2006).

Previous intraspecific studies on a number of taxa have found little evidence for genetic discontinuities in the Gulf of Mexico (but see Gurgel et al. 2004), although this may have resulted from a variety of factors including limited sampling and studies of species with high dispersal potential (e.g. pelagic fish) (Avise et al. 1987, Reeb \& Avise 1990, Gold \& Richardson 1998, Heist \& Gold 2000, Blandon et al. 2001, Gold \& Turner 2002, Herke \& Foltz 2002, Ball \& Chapman 2003). The 2 genetic discontinuities we found occur near previously described biogeographic boundaries (Mobile Bay and Florida). The presence of a vicariance zone has been described for some closely related species of fish and invertebrates near Mobile Bay in the northern Gulf (e.g. Bert 1986, McClure \& McEachran 1992, Felder \& Staton 1994, Gurgel et al. 2004, Harrison 2004, Bilodeau et al. 2005). The Florida sampling localities are along the northern edge of the Caribbean faunal biogeographic province, which is located just below the more temperate Gulf of Mexico province (Briggs 1974, Engle \& Summers 2000).

We did not find a strong transition zone in the northern Gulf near Mobile Bay, and Bayesian clustering did not reveal a clear signal of admixture in this area arising from 2 differentiated populations coming into secondary contact as is observed in Fundulus heteroclitus (Adams et al. 2006). These results suggest that if $F$. 
grandis had been forced into southern refugia (e.g. Barnwell \& Thurman 1984), it may not have been for long periods of time or, alternatively, there may have been many episodes of extinction-recolonization in the northern Gulf during the Pleistocene. Another possibility is that recolonization of the northern Gulf populations that we sampled may have occurred predominantly from the western Gulf, and a zone of secondary contact with more southeastern populations occurs between Mobile Bay and Tampa Bay. The Florida populations appear to be more highly differentiated from the other Gulf populations, above what is expected by distance alone, suggesting the presence of a transition zone in that region. More continuous sampling is needed to determine whether there is a zone of secondary contact in this region consistent with the southern refugia hypothesis.

The decrease in allelic richness with increasing latitude in the Gulf and the fact that allelic richness is relatively higher in the southwestern and southeastern Gulf compared to the northern populations is consistent with recolonization of the northern Gulf from southern refugia. A decrease in genetic diversity with latitude is usually hypothesized to result from the recolonization of northern habitats after the retreat of the glaciers during the Pleistocene and has been described for a number of taxa (Hewitt 2000, Adams et al. 2006, Haney et al. 2007).

Alternatively, the observed genetic discontinuities in Fundulus grandis may simply be located in areas that either have geographic features or selective regimes that limit dispersal and are not indicative of historical transition zones. This may be especially true of the Mobile Bay area that was relatively less differentiated from the western populations. Large bays along the east coast of North America are believed to be effective dispersal barriers for $F$. heteroclitus, which prefer shallow, near-shore water (Duvernell et al. 2008), and may explain the genetic differentiation of F. grandis located at Mobile Bay and Tampa Bay. It is currently unknown what potential selective factors might limit gene flow in this species, although adaptations to differing levels of hypoxia, salinity, and temperature are possibilities. A finer scale genetic study of the Mobile and Tampa Bay areas may reveal the nature of the dispersal barriers in these regions (e.g. Duvernell et al. 2008). Recent disturbances such as hurricanes could also affect the population genetic structure of $F$. grandis by altering the distribution of suitable habitat or by killing large numbers of individuals, resulting in decreased population sizes or local extinction and recolonization events. We did not find evidence of recent bottlenecks or founder events in either Mobile Bay or Florida. The effects of hurricanes on near-shore fish populations are believed to be relatively transitory (Greenwood et al. 2006).
The estimation of gene flow between populations using estimators such as $F_{\mathrm{ST}}$ assumes the presence of migration-drift equilibrium (e.g. Hutchison \& Templeton 1999, Castric \& Bernatchez 2003, Austin et al. 2004). Populations with a stepping stone population structure are expected to exhibit a pattern of IBD when they are at migration-drift equilibrium (Kimura \& Weiss 1964, Crow \& Aoki 1984, Slatkin 1993, Hutchison \& Templeton 1999). The relatively strong IBD relationship ( $\mathrm{r}=0.89$ ) and a $y$-intercept near the origin (0) among the populations west of Mobile Bay suggest these populations may be at migration-drift equilibrium. The genetic discontinuities revealed in Mobile Bay and especially Florida suggest that populations located along the entire Gulf coast are probably not at migration-drift equilibrium; therefore, inferences about the effects of gene flow and selection on population structure must take these patterns into consideration.

As expected, patterns of nuclear microsatellite variation suggest that contemporary gene flow is limited in Fundulus grandis and occurs mainly between neighboring sites. Indications of historical influences on the current day genetic structure of $F$. grandis include a negative relationship between genetic diversity and latitude and evidence of genetic discontinuities at hypothesized biogeographic boundaries, although these discontinuities may be related to current day dispersal barriers. Genotyping these populations with a mitochondrial DNA marker and extending the sampling range to include populations from more southern latitudes (i.e. extreme southern and eastern Florida and northern Mexico) could improve our understanding of the patterns we have found in the present study. Although not as dramatic as the Atlantic versus Gulf split seen in many species, results suggest that microsatellite markers can uncover subtle evidence for historical influences and genetic discontinuities within the Gulf of Mexico. More intraspecific studies are needed on other estuarine-dependent species within the Gulf to test the generality of the southern refugia hypothesis.

Acknowledgements. We thank M. Vaughn for collecting samples and J. VanWye for laboratory assistance. This research was supported by NSF BE/GEN-EN 0221879 and NIH/NHLBI HL65470. We also thank A. Hale and 4 anonymous reviewers for commenting on earlier versions of this manuscript and J. Kool for providing Fig. 1.

\section{LITERATURE CITED}

Adams SM, Oleksiak MF, Duvernell DD (2005) Microsatellite primers for the Atlantic coastal killifish, Fundulus heteroclitus, with applicability to related Fundulus species. Mol Ecol Notes 5:275-277

Adams SM, Lindmeier JB, Duvernell DD (2006) Microsatellite 
analysis of the phylogeography, Pleistocene history and secondary contact hypotheses for the killifish, Fundulus heteroclitus. Mol Ecol 15:1109-1123

Austin JD, Loughheed SC, Boag PT (2004) Controlling for the effects of history and nonequilibrium conditions in gene flow estimates in northern bullfrog (Rana catesbeiana) populations. Genetics 168:1491-1506

Avise JC (1996) Toward a regional conservation genetics perspective: phylogeography of faunas in the southeastern United States. In: Avise JC, Hamrick JL (eds) Conservation genetics. Chapman \& Hall, New York, p 431-470

Avise JC (2000) Phylogeography. Harvard University Press, Cambridge, MA

- Avise JC, Reeb CA, Saunders NC (1987) Geographic population structure and species differences in mitochondrial DNA of mouthbrooding marine catfishes (Ariidae) and demersal spawning toadfishes (Batrachoididae). Evolution 41:991-1002

Ball AO, Chapman RW (2003) Population genetic analysis of white shrimp, Litopenaeus setiferus, using microsatellite genetic markers. Mol Ecol 12:2319-2330

Barnwell FH, Thurman CL (1984) Taxonomy and biogeography of the fiddler crabs (Ocypodidae, genus $U_{c a}$ ) of the Atlantic and Gulf coasts of eastern North America. Zool J Linn Soc 81:23-87

Beheregaray LB, Sunnucks P (2001) Fine-scale genetic structure, estuarine colonization and incipient speciation in the marine silverside fish Odontesthes argentinensis. Mol Ecol 10:2849-2866

Bert TM (1986) Speciation in western Atlantic stone crabs (genus Menippe): the role of geological processes and climatic events in the formation and distribution of species. Mar Biol 93:157-170

Bilodeau AL, Felder DL, Neigel JE (2005) Population structure at two geographic scales in the burrowing crustacean Callichirus islagrande (Decapoda, Thalassinidea): historical and contemporary barriers to planktonic dispersal. Evolution 59:2125-2138

Bilton DT, Paula J, Bishop JDD (2002) Dispersal, genetic differentiation and speciation in estuarine organisms. Estuar Coast Shelf Sci 55:937-952

Blandon LR, Ward R, King TL, Karel WJ, Monaghan JP (2001) Preliminary genetic population structure of southern flounder, Paralichthys lethostigma, along the Atlantic Coast and Gulf of Mexico. Fish Bull 99:671-678

Bloom AL (1983) Sea level and coastal morphology of the United States through the late Wisconsin glacial maximum. In: Porter SC (ed) The Late Pleistocene, Vol 1. University of Minnesota, Minneapolis, MN, p 215-229

Briggs JC (1974) Marine zoogeography. McGraw-Hill, New York

Brookfield JFY (1996) A simple new method for estimating null allele frequency from heterozygote deficiency. Mol Ecol 5:453-455

> Brunner CA (1982) Paleoceanography of surface waters in the Gulf of Mexico during the late Quanternary. Quat Res 17: 105-119

Burridge CP, Hurt AC, Farrington LW, Coutin PC, Austin CM (2004) Stepping stone gene flow in an estuarine-dwelling sparid from south-east Australia. J Fish Biol 64:805-819

Castric V, Bernatchez L (2003) The rise and fall of isolation by distance in the anadromous brook charr (Salvelinus fontinalis Mitchill). Genetics 163:983-996

> Chenoweth SF, Hughes JM (2003) Oceanic interchange and nonequilibrium population structure in the estuarine dependent Indo-Pacific tasselfish, Polynemus sheridani. Heredity 80:187-197
Cornuet JM, Luikart G (1996) Description and power analysis of two tests for detecting recent population bottlenecks from allele frequency data. Genetics 144:2001-2014

Cornuet JM, Piry S, Luikart G, Estoup A, Solignac M (1999) New methods employing multilocus genotypes to select or exclude populations as origins of individuals. Genetics 153:1989-2000

Crow JF, Aoki K (1984) Group selection for a polygenic behavioral trait: estimating the degree of population subdivision. Proc Natl Acad Sci USA 81:6073-6077

> Durand JD, Tine M, Panfili J, Thiaw OT, Lae R (2005) Impact of glaciations and geographic distance on the genetic structure of a tropical estuarine fish, Ethmalosa fimbriata (Clupeidae, S. Bowdich, 1825). Mol Phylogenet Evol 36: $277-287$

> Duvernell DD, Lindmeier JB, Faust KE, Whitehead A (2008) Relative influences of historical and contemporary forces shaping the distribution of genetic variation in the Atlantic killifish, Fundulus heteroclitus. Mol Ecol 17:1344-1360

Engle VD, Summers JK (2000) Biogeography of benthic macroinvertebrates in estuaries along the Gulf of Mexico and western Atlantic coasts. Hydrobiologia 436:17-33

> Estoup A, Jarne P, Cornuet JM (2002) Homoplasy and mutation model at microsatellite loci and their consequences for population genetics analysis. Mol Ecol 11:1591-1604

Evanno G, Regnaut S, Goudet J (2005) Detecting the number of clusters of individuals using the software STRUCTURE: a simulation study. Mol Ecol 14:2611-2620

> Felder DL, Staton JL (1994) Genetic differentiation in transFloridian species complexes of Sesarma and Uca (Decapoda, Brachyura). J Crustac Biol 14:191-209

Gold JR, Richardson LR (1998) Mitochondrial DNA diversification and population structure in fishes from the Gulf of Mexico and western Atlantic. J Hered 89:404-414

Gold JR, Turner TF (2002) Population structure of red drum (Sciaenops ocellatus) in the northern Gulf of Mexico, as inferred from variation in nuclear-encoded microsatellites. Mar Biol 140:249-265

Goudet J (2001) FSTAT, a program to estimate and test gene diversities and fixation indices (version 2.9.3). Available at: http://www2.unil.ch/popgen/softwares/fstat.htm

Goudet J, Raymond M, deMeeus T, Rousset F (1996) Testing differentiation in diploid populations. Genetics 144: 1933-1940

> Greeley MS, MacGregor R III (1983) Annual and semilunar reproductive cycles of the Gulf killifish, Fundulus grandis, on the Alabama Gulf coast. Copeia 1983:711-718

Greenwood MFD, Stevens PW, Matheson RE Jr (2006) Effects of the 2004 hurricanes on the fish assemblages in two proximate southwest Florida estuaries: change in the context of interannual variability. Estuar Coasts 29: 985-996

Grosberg R, Cunningham CW (2001) Genetic structure in the sea: from populations to communities. In: Bertness MD, Gaines S, Hay ME (eds) Marine community ecology. Sinauer Associates, Sunderland, MA, p 61-84

> Gurgel CFD, Fredericq S, Norris JN (2004) Phylogeography of Gracilaria tikvahiae (Gracilariaceae, Rhodophyta): a study of genetic discontinuity in a continuously distributed species based on molecular evidence. J Phycol 40:748-758

Haney RA, Silliman BR, Fry AJ, Layman CA, Rand DM (2007) The Pleistocene history of the sheepshead minnow (Cyprinodon variegatus): non-equilibrium evolutionary dynamics within a diversifying species complex. Mol Phylogenet Evol 43(3):743-754

> Harrison JS (2004) Evolution, biogeography, and the utility of mitochondrial $16 \mathrm{~s}$ and COI genes in phylogenetic analysis 
of the crab genus Austinixa (Decapoda: Pinnotheridae). Mol Phylogenet Evol 30:743-754

Heist EJ, Gold JR (2000) DNA microsatellite loci and genetic structure of red snapper in the Gulf of Mexico. Trans Am Fish Soc 129:469-475

Herke SW, Foltz DW (2002) Phylogeography of two squid (Loligo pealei and L. plei) in the Gulf of Mexico and northwestern Atlantic Ocean. Mar Biol 140:103-115

Hewitt G (2000) The genetic legacy of the Quaternary ice ages. Nature 405:907-913

> Hutchison DW, Templeton AR (1999) Correlation of pairwise genetic and geographic distance measures: inferring the relative influences of gene flow and drift on the distribution of genetic variability. Evolution 53:1898-1914

Imbrie J, McIntyre A, Moore TCJ (1983) The ocean around North America at the last glacial maximum. In: Porter SC (ed) The Late Pleistocene, Vol 1. University of Minnesota, Minneapolis, MN, p 230-238

Kimura M, Weiss GH (1964) The stepping stone model of population structure and the decrease of genetic correlation with distance. Genetics 49:561-576

Lee D, Gilbert CR, Hocutt CH, Jenkins RE, McAllister DE, Stauffer JR Jr (1980) Atlas of North American freshwater fishes. North Carolina State Museum of Natural History, Raleigh

Lemaire C, Allegrucci G, Naciri M, Bahri-Sfar L, Kara H, Bonhomme F (2000) Do discrepancies between microsatellite and allozyme variation reveal differential selection between sea and lagoon in the sea bass (Dicentrarchus labrax)? Mol Ecol 9:457-467

Luikart G, Allendorf FW, Cornuet JM, Sherwin WB (1998) Distortion of allele frequency distributions provides a test for recent population bottlenecks. J Hered 89:238-247

McClure MR, McEachran JD (1992) Hybridization between Prionotus alatus and $P$. paralatus in the Northern Gulf of Mexico (Pisces, Triglidae). Copeia 1992:1039-1046

McIntyre A, Kipp AG, Be AWH, Crowley T and others (1976) Glacial North America 18,000 years ago: a climate reconstruction. In: Cline RM, Hays JD (ed) Late Quaternary paleoceanography and paleoclimatology. Geological Society of America, Boulder, CO, p 43-76

Pampoulie C, Gysels ES, Maes GE, Hellemans B, Leentjes V, Jones AG, Volckaert FAM (2004) Evidence for fine-scale genetic structure and estuarine colonisation in a potential high gene flow marine goby (Pomatoschistus minutus). Heredity 92:434-445

Peakall R, Smouse PE (2006) GENALEX 6: genetic analysis in Excel. Population genetic software for teaching and research. Mol Ecol Notes 6:288-295

Piry S, Luikart G, Cornuet JM (1999) BOTTLENECK: a computer program for detecting recent reductions in the effective population size using allele frequency data. J Hered 90:502-503

Piry S, Alapetite A, Cornuet JM, Paetkau D, Baudouin L, Estoup A (2004) GeneClass2: a software for genetic

Editorial responsibility: Jana Davis,

Annapolis, Maryland, USA assignment and first-generation migrant detection. J Hered 95:536-539

Pritchard JK, Wen W (2003) Documentation for structure software: version 2.2. Available at: http://pritch.bsd.uchicago. edu

Pritchard JK, Stephens M, Donnelly P (2000) Inference of population structure using multilocus genotype data. Genetics 155:945-959

Purcell JFH, Cowen RK, Hughes CR, Williams DA (2006) Weak genetic structure indicates strong dispersal limits: a tale of two coral reef fish. Proc R Soc Lond B 273: 1483-1490

Rannala B, Mountain JL (1997) Detecting immigration by using multilocus genotypes. Proc Natl Acad Sci USA 94: 9197-9201

Raymond M, Rousset F (1995) GENEPOP (version 1.2): population genetics software for exact tests and eucumenicism. J Hered 86:248-249

Reeb CA, Avise JC (1990) A genetic discontinuity in a continuously distributed species: mitochondrial DNA in the American oyster, Crassostrea virginica. Genetics 124: 397-406

Skinner MA, Courtenay SC, Parker WR, Curry RA (2005) Site fidelity of mummichogs (Fundulus heteroclitus) in an Atlantic Canadian estuary. Water Qual Res J Can 40: 288-298

Slatkin M (1993) Isolation by distance in equilibrium and nonequilibrium populations. Evolution 47:264-279

Soltis DE, Morris AB, McLachlan JS, Manos PS, Soltis PS (2006) Comparative phylogeography of unglaciated eastern North America. Mol Ecol 15:4261-4293

Stanley SM (1986) Anatomy of a regional mass extinction. Plio-Pleistocene decimation of the western Atlantic bivalve fauna. Palaios 1:17-36

Sweeney J, Deegan L, Garritt R (1998) Population size and site fidelity of Fundulus heteroclitus in a macrotidal saltmarsh creek. Biol Bull 195:238-239

Van Oosterhout C, Hutchinson WF, Wills DPM, Shipley P (2004) MICRO-CHECKER: software for identifying and correcting genotyping errors in microsatellite data. Mol Ecol Notes 4:535-538

Waples RS (1998) Separating the wheat from the chaff: patterns of genetic differentiation in high gene flow species. J Hered 89:438-450

> Ward RD, Woodwark M, Skibinski DOF (1994) A comparison of genetic diversity levels in marine, fresh-water, and anadromous fishes. J Fish Biol 44:213-232

> Watts RJ, Johnson MS (2004) Estuaries, lagoons and enclosed embayments: habitats that enhance population subdivision of inshore fishes. Mar Freshw Res 55:641-651

Weir BS, Cockerham CC (1984) Estimating F-statistics for the analysis of population structure. Evolution 38:1358-1370

Whitehead A, Crawford DL (2006) Neutral and adaptive variation in gene expression. Proc Nat Acad Sci USA 103: 5425-5430

Submitted: March 7, 2008; Accepted: September 15, 2008

Proofs received from author(s): December 9, 2008 